\title{
Effects of Cadmium Chloride and Glyphosate on Antioxidants as Biochemical Biomarkers in Nile Tilapia
}

\author{
Mohammed M Abd-Allah', Ashraf A Ramadan², Noha M Said ${ }^{3}$, Ibrahim H Ibrahim², and Esam A Abdel-karim ${ }^{2}$ \\ ${ }^{1}$ Faculty of Sciences, Department of Chemistry, Zagazig University, Zagazig, Sharkia, Egypt \\ ${ }^{2}$ Fish Genetics and Breeding Department, Central Laboratory for Aquaculture Research, Abbassa, Agriculture Research Center, Egypt \\ ${ }^{3}$ Biochemistry Division, Faculty of Sciences, Department of Chemistry, Zagazig University, Zagazig, Sharkia, Egypt, Research Center, Egypt
}

\begin{abstract}
The present study was undertaken to evaluate the effects of cadmium chloride and commercial formulation of glyphosate $\left(\right.$ Roundup $\left.^{\circledR}\right)$ on oxidative stress biomarkers in the Nile tilapia, Oreochromis niloticus through three exposure periods with different concentrations of $\mathrm{LC}_{50}$. The $96 \mathrm{~h}-\mathrm{LC}_{50}$ were determined for $\mathrm{CdCl}_{2}(132 \mathrm{mg} / \mathrm{l})$, glyphosate $(9.63 \mathrm{mg} / \mathrm{l}), \mathrm{CdCl}_{2}$ in mixture $(41.30 \mathrm{mg} / \mathrm{l})$ and glyphosate in mixture $(2.75 \mathrm{mg} / \mathrm{l})$, respectively. The fish was exposed to these concentrations separately and mixed for 4 days as well as two sublethal concentrations $\left(1 / 4\right.$ and $1 / 10$ LC $_{50}$ ) for 8 days and 45 days, respectively. Gills and liver cells of the exposed fish were taken after 4,8 and 45 days to investigate the variation in activity of lipid peroxidation malonaldehyde (MDA) and antioxidant enzymes of catalase (CAT), superoxide dismutase (SOD), glutathione-S-transferase (GST) and reduced glutathione (GSH). Where, in gills activity levels of SOD decreased after 4, 8 days in all treatments due to high concentration of pollutants but increased after 45 days in glyphosate and cadmium due to low oxidative stress and decreased in mixture. Also, in the liver activity of SOD decreased in glyphosate and cadmium and increased in mixture in periods 4,8 days but, increased in 45 days in glyphosate and mixture and decreased in cadmium due to its toxicity. The activity of CAT decreased in gills and liver after 4 days but increased after 8,45 days due to low concentration of contaminants. The activity of GST increased in gills and liver after 4,8 days but decreased in liver after 45 days. The activity of GSH reduced in gills and liver in all treatments after all periods due to strong oxidative stress. MDA level increased as a marker of oxidative in gills and liver in all treatments after all periods.
\end{abstract}

Keywords: Nile tilapia; Glyphosate; Cadmium chloride; Biomarker; Antioxidant enzymes; Oxidative stress

\section{Introduction}

Fish was used as a bioindicators for the detection pollution of the aquatic environment [1]. Fish occupies the top of food chain and is the main source of protein without fats to keep people fit. Heavy metals transfer by water through fish causing diseases for consumers [2]. Nile tilapia is the most important and promising aquaculture fish species in Egypt, representing more than $80 \%$ of total tilapias production [3]. Egypt ranked the second in cultured tilapia's production directly after China [4]. Now, Oreochromis niloticus is the main cultured fish species in Egypt [5]. Tilapia species are a very important group of cultured fish for many causes as fast growth, adaptation with the least quality of water and salinity [6], Handling, food conversion, disease resistance and good consumer taste [7].

Bio-accumulation of heavy metals in aquatic organisms led to a strong threat to health [8]. Heavy metals from industries disturb the aquatic environment [9]. Laboratory and field studies illustrated that accumulation of heavy metals in tissues should depends on concentrations of metals, period of exposure and some environmental factors such as temperature of water, dissolved oxygen concentration, hydrogen ion concentration, hardness, salinity, alkalinity and dissolved organic carbon [10]. Cadmium is absorbed directly by organisms from water and accumulate in tissues of liver, stomach and gills of fish causing pathological changes [11].

Glyphosate, [ $N$-(phosphoromethyl) glycine], is an herbicide used in agriculture to eliminate the growth of grasses, sedges and woodyshrubs [12]. It is used to eliminate aquatic weeds which, spread in the water of fish ponds, lakes and canals [13]. It is considered the most developed herbicide all over the world [14]. Glyphosate only has low toxic effect on aquatic organisms but commercial Roundup has a more toxic effect due to the addition of polyoxyethylene amine (POEA) to its formulation
[15]. POEA is responsible for ROS generation in freshwater fish Channa punctatus [16]. Glyphosate spreads in aquatic environment due to the crops along the water bodies. Thus, fish is considered as a bio-indicators for contamination with herbicide [17].

Oxidative stress means the difference between level of ROS "Reactive Oxygen Species" and the defensive ability of living organisms [18]. Antioxidants are chemical compounds contain monohydroxy and polyhydroxy phenol. They perform slow down the lipid peroxidation [19]. Herbicides led to damage the membrane lipids peroxidation causing injury and death of the cell [20]. Oxidation of polyunsaturated fatty acids is an important physiological process in cellular maturity called lipid peroxidation [21]. And lipid mobilization [22]. Xenobiotics caused cellular membrane damage as lipid peroxidation (LPO) [23]. Thus, LPO is considered as a bioindicator of oxidative damage of cellular components and ROS production cause oxidative damage for lipids and proteins [24]. Catalase is the most active antioxidant defence enzymes due to its easily combination with SOD and other $\mathrm{H}_{2} \mathrm{O}_{2}$ producers. So, activity of CAT was analyzed in liver tissues of fish either by gel activity staining method or spectrophotometric biochemical method [25]. The

*Corresponding author: Esam A. Abdel-karim, Fish Genetics and Breeding Department, Central Laboratory for Aquaculture Research, Abbassa, Agriculture Research Center, Egypt, Tel: +20 55 2364612; E-mail: esam.abdelkarim@yahoo.com

Received September 04, 2018; Accepted January 24, 2019; Published January 31, 2019

Citation: Abd-Allah MM, Ramadan A A, Said NM, Ibrahim IH, Abdel-karim EA (2019) Effects of Cadmium Chloride and Glyphosate on Antioxidants as Biochemical Biomarkers in Nile Tilapia. J Aquac Res Development 10: 561. doi: 10.4172/21559546.1000561

Copyright: (c) 2019 Abd-Allah MM, et al. This is an open-access article distributed under the terms of the Creative Commons Attribution License, which permits unrestricted use, distribution, and reproduction in any medium, provided the original author and source are credited. 
Citation: Abd-Allah MM, Ramadan A A, Said NM, Ibrahim IH, Abdel-karim EA (2019) Effects of Cadmium Chloride and Glyphosate on Antioxidants as Biochemical Biomarkers in Nile Tilapia. J Aquac Res Development 10: 561. doi: 10.4172/2155-9546.1000561

Page 2 of 6

activity of CAT high in almost all tissues, when compared with controls [26].

Superoxide dismutase is responsible for the dismutation of the superoxide anion radical to $\mathrm{H}_{2} \mathrm{O}_{2}$. Exposition of liver to pesticides or heavy metals led to inhibition activity of these enzymes [27]. Glutathione-S-transferase (GST) is an important enzyme to reduce glutathione and protect the cell against the effects of xenobiotics [28]. Xenobiotics, such as glyphosate induce redox cycling causing oxidative damage [29]. GST acts as catalytic agent in biotransformation process by conjugation of metabolites, as xenobiotic metabolites. Then, lipoperoxidation products with GSH convert toxic compound into other with low toxicity. Reduced glutathione (GSH) is considered as Non-enzymatic antioxidant in the cell and is a cofactor for the mechanism of GST and GPx [30]. Similarly, Shalaby et al., [31] showed that the biochemical changes in Nile tilapia after exposure glyphosate herbicide. The present study to evaluate the effects of $\mathrm{CdCl}_{2}$, glyphosate and their mixture on antioxidants as biomarkers in the Nile tilapia.

\section{Materials and Methods}

\section{Determination of lethal concentration $\mathrm{LC}_{50}$ through experi- ments}

The freshwater fish Nile tilapia (Oreochromis niloticus) fingerlings were collected from a local farm of "Central Laboratory for Aquaculture Research", Abo-Hammad, Sharkia, Egypt. The weight and the length were measured and scored of $32.0 \pm 3.0 \mathrm{~g}$ and $13.0 \pm 2.0 \mathrm{~cm}$, respectively. Acclimatized fish were distributed in small aquaria to determine the 96h-LC ${ }_{50}$ by OECD [32] and calculated by Weil [33]. The $96 \mathrm{~h}-\mathrm{LC}_{50}$ were determined for $\mathrm{CdCl}_{2}(132 \mathrm{mg} / \mathrm{l})$, glyphosate $(9.63 \mathrm{mg} / \mathrm{l}), \mathrm{CdCl}_{2}$ in mixture $(41.30 \mathrm{mg} / \mathrm{l})$ and glyphosate in mixture $(2.75 \mathrm{mg} / \mathrm{l})$, respectively were used in the first experiment. Second experiment used $1 / 4 \mathrm{LC}_{50}$ in 8 days and $1 / 10 \mathrm{LC}_{50}$ was used in 45 days through the third experiment. Three replicates were used for each experiment, as well as control.

\section{The physicochemical parameters of experimental water}

The physicochemical parameters of the water used during the experiment were: temperature $24-27^{\circ} \mathrm{C}, \mathrm{pH} 7.81-7.89$, nitrite $0.081-$ $0.242 \mathrm{mg} / \mathrm{l}$, orthophosphate $0.042-0.17 \mathrm{mg} / \mathrm{l}$, total ammonia $0.2-0.4$ $\mathrm{mg} / \mathrm{l}$, dissolved oxygen concentration ranged from 7.3 to $7.8 \mathrm{mg} / \mathrm{l}$, while total hardness ranged from 190 to $206 \mathrm{mg} / \mathrm{l}$ and total alkalinity ranged from 75 to $165 \mathrm{mg} / \mathrm{l}$ as $\mathrm{CaCO}_{3}$. But the concentration of heavy metal in water was measured by atomic absorption apparatus such as $\mathrm{Cu}, \mathrm{Cd}, \mathrm{Zn}, \mathrm{Mn}, \mathrm{Pb}$ and Fe were $0.027 \mathrm{mg} / \mathrm{l}, 0.00 \mathrm{mg} / \mathrm{l}, 0.111 \mathrm{mg} / \mathrm{l}, 0.083$ $\mathrm{mg} / \mathrm{l}, 0.00 \mathrm{mg} / \mathrm{l}$ and $1.775 \mathrm{mg} / \mathrm{l}$ respectively. Where these results were within permissible limits.

\section{Determination of oxidative parameters activity}

Samples preparation: Fish homogenized with Teflon tissues. Homogenizing tissues on ice ensure that tissue remains cold. Fish sample liver and gills were homogenized in 10vol. (w/v) of ice cold $50 \mathrm{mM}$ potassium-phosphate buffer (homogenization buffer $\mathrm{pH} 7.4$ ) with a stable number of strokes and centrifuged at $10000 \mathrm{rpm}$ for 20 min. at $4^{\circ} \mathrm{C}$ to obtain the supernatant for oxidative stress markers (SOD; MDA; GSH; GST and CAT).

Catalase activity in tissues: Catalase activity (CAT) in liver and gills tissues was determined according to the method of Aebi [34] in which the disappearance of hydrogen peroxide is followed spectrophotometrically at $240 \mathrm{~nm}$ where, the enzyme catalyzes the decomposition of $\mathrm{H}_{2} \mathrm{O}_{2}$ into water and oxygen.
Superoxide dismutase activity in tissue: Superoxidedismutase (SOD) was determined according to the method of Marklund SL and Marklund G [35]. The method depends on the spontaneous autooxidation of pyrogallol at alkaline $\mathrm{pH}$, and the production of superoxide anion radical $\mathrm{O}^{2-}$. This enhances auto-oxidation of pyrogallol. Autooxidation is manifested by an increase in absorbance at $420 \mathrm{~nm}$. The presence of SOD in the reaction medium leads to the removal of $\mathrm{O}^{2-}$.

Determination of reduced glutathione: Reduced glutathione (GSH) was determined according to the method described by Beutler et al. [36] depends on the fact that both protein and non-protein $\mathrm{SH}$ group (mainly GSH) react with Ellman's reagent [5, 5'-dithiobis (2 nitrobenzoic acid)] (DTNB) to form a stable yellow color of 5-mercapto2-nitrobenzoic acid, which can be measured calorimetrically at $412 \mathrm{~nm}$.

Determination of glutathione S-transferase activity: The glutathione S-transferase activity was assayed spectrophotometrically using the method of Habig et al. [37] which is based on the measure of yellow color developed as a result of the conjugation of 1-choloro-2, 4-dinitrobenzen; (CDNB) with GSH at $340 \mathrm{~nm}$.

Determination of lipid peroxidation (MDA): Lipid peroxidation was assayed by the colorimetric method adopted by Ohkawa et al. [38]. This method defends on the reaction of lipid peroxides in liver and gill tissues with thiobarbituric acid at the optimum $\mathrm{pH}(3.5)$ at $95^{\circ} \mathrm{C}$ heating for $60 \mathrm{~min}$. the produced red pigment then, estimated by the absorbance at $532 \mathrm{~nm}$.

\section{Statistical analysis}

The experimental data were processed with SPSS 15.0 statistical software. One-way ANOVA (analysis of variance) was performed to estimate the differences between control and exposure fish to glyphosate or cadmium chloride and mixture. All data are presented as Mean \pm S.E. (standard error of the mean). Statistically significant difference was set as $\mathrm{p}<0.05$ [39].

\section{Results and Discussion}

Aquatic contamination by pesticides and heavy metals led to hazard effects on the growth, survival, reproduction of aquatic animals and cause mortality of fish in streams, lakes and ponds all over the world. Production of ROS can cause oxidative damage [40]. ROS can attack lipids, proteins and DNA in living cells led to disturbance in physiological cell processes $[41,42]$. So, data presented in Table 1 indicate that the effect of $96 \mathrm{~h}-\mathrm{LC}_{50}$ of glyphosate, $\mathrm{CdCl}_{2}$ and mixture treatments on the activity of antioxidant enzymes due to oxidative stress on gills and liver of Oreochromis niloticus after 4 days.

Data of oxidative parameters for gills at short time of exposure 4 days with high concentration $96 \mathrm{~h}-\mathrm{LC}_{50}$ showed significantly reduced activity of SOD and CAT in mixture treatment followed by glyphosate and $\mathrm{CdCl}_{2}$, respectively. High reduction activity of mixture treatment due to occurrence antagonistic effect between $\mathrm{CdCl}_{2}$ and glyphosate causing high oxidative stress. Reduction activity of glyphosate and $\mathrm{CdCl}_{2}$ due to short time exposure. Activity increased of GST in glyphosate treatment due to substance of POEA which added to glyphosate which causing oxidative stress but, nearly no significance in treatment of cadmium and mixture due to low oxidative stress. Also, no significance activity of GSH in all treatments due to short time of exposure. Activity of MDA significantly increased in glyphosate treatment followed by mixture and $\mathrm{CdCl}_{2}$ due to high oxidative stress where, oxidative stress of glyphosate due to high toxicity of emulsifier surfactant substance loaded but, in the case of mixture due to occurrence synergistic effect between $\mathrm{CdCl}_{2}$ 
Citation: Abd-Allah MM, Ramadan A A, Said NM, Ibrahim IH, Abdel-karim EA (2019) Effects of Cadmium Chloride and Glyphosate on Antioxidants as Biochemical Biomarkers in Nile Tilapia. J Aquac Res Development 10: 561. doi: 10.4172/2155-9546.1000561

Page 3 of 6

\begin{tabular}{|c|c|c|c|c|c|c|}
\hline \multirow{3}{*}{ Tissues } & \multicolumn{6}{|c|}{ Exposure period (96 hrs) 4 days with $\mathrm{L}_{\mathrm{c5}} 0$} \\
\hline & \multirow{2}{*}{$\begin{array}{l}\text { Oxidative stress } \\
\text { treatments }\end{array}$} & \multicolumn{5}{|c|}{ Enzymatic \& non-enzymatic antioxidants (Mean \pm S.E) } \\
\hline & & SOD & CAT & GST & GSH & MDA \\
\hline \multirow{4}{*}{ Gills } & Control & $74.34 \pm 1.95^{\mathrm{b}, \mathrm{d}}$ & $22.88 \pm 0.58^{b, c, d}$ & $18.06 \pm 0.22^{\mathrm{b}}$ & $87.50 \pm 0.94$ & $61.08 \pm 0.29^{b, c, c}$ \\
\hline & Glyphosate & $\begin{array}{c}58.54 \pm 1.66^{\mathrm{a}, \mathrm{c}} \\
21 \% \downarrow\end{array}$ & $\begin{array}{c}15.79 \pm 0.28^{\mathrm{a}, \mathrm{c}} \\
31 \% \downarrow\end{array}$ & $\begin{array}{c}22.912 \pm 1.91^{\mathrm{a}, \mathrm{c}, \mathrm{d}} \\
27 \% \uparrow\end{array}$ & $\begin{array}{c}87.5 \pm 0.94 \\
0.04 \% \uparrow\end{array}$ & $\begin{array}{c}105.5 \pm 2.21^{\mathrm{a}, \mathrm{c}, \mathrm{c}} \\
73 \% \uparrow\end{array}$ \\
\hline & Cadmium & $\begin{array}{c}68.10 \pm 3.59^{\mathrm{b}, \mathrm{d}} \\
8 \% \downarrow\end{array}$ & $\begin{array}{c}19.66 \pm 0.89^{\mathrm{a}, \mathrm{b}, \mathrm{d}} \\
14 \% \downarrow\end{array}$ & $\begin{array}{c}18.518 \pm 0.63^{\mathrm{b}} \\
2 \% \uparrow\end{array}$ & $\begin{array}{c}87.03 \pm 0.52 \\
0.5 \% \downarrow\end{array}$ & $\begin{array}{c}77.47 \pm 1.69^{\mathrm{a}, \mathrm{b}, \mathrm{c}} \\
27 \% \uparrow\end{array}$ \\
\hline & Mixture & $\begin{array}{c}55.99 \pm 0.62^{\mathrm{a}, \mathrm{c}} \\
25 \% \downarrow\end{array}$ & $\begin{array}{c}15.43 \pm 1.12^{\mathrm{a}, \mathrm{c}} \\
32 \% \downarrow\end{array}$ & $\begin{array}{c}17.59 \pm 1.29^{\mathrm{b}} \\
3 \% \downarrow\end{array}$ & $\begin{array}{c}86.02 \pm 0.79 \\
2 \% \downarrow\end{array}$ & $\begin{array}{c}84.94 \pm 3.47^{\mathrm{a}, \mathrm{b}, \mathrm{c}} \\
39 \% \uparrow\end{array}$ \\
\hline \multirow{4}{*}{ Liver } & Control & $72.46 \pm 1.73^{b, c}$ & $65.91 \pm 4.24^{\mathrm{d}}$ & $48.37 \pm 3.11^{\mathrm{b}, \mathrm{c}, \mathrm{d}}$ & $95.55 \pm 0.23^{b, c, d}$ & $55.22 \pm 2.48^{\mathrm{b}, \mathrm{c}, \mathrm{c}}$ \\
\hline & Glyphosate & $\begin{array}{c}52.47 \pm 1.43^{\mathrm{a}, \mathrm{c}, \mathrm{d}} \\
27 \% \downarrow\end{array}$ & $\begin{array}{c}63.25 \pm 1.88^{d} \\
4 \% \downarrow\end{array}$ & $\begin{array}{c}81.48 \pm 2.22^{\mathrm{a}, \mathrm{c}, \mathrm{d}} \\
67 \% \uparrow\end{array}$ & $\begin{array}{c}93.33 \pm 0.38^{\mathrm{a}, \mathrm{c}} \\
2 \% \downarrow\end{array}$ & $\begin{array}{c}71.65 \pm 6.42^{\mathrm{a}, \mathrm{c}, \mathrm{c}} \\
30 \% \uparrow\end{array}$ \\
\hline & Cadmium & $\begin{array}{c}45.50 \pm 2.46^{\mathrm{a}, \mathrm{b}, \mathrm{d}} \\
37 \% \downarrow\end{array}$ & $\begin{array}{c}58.54 \pm 1.35 \\
11 \% \downarrow\end{array}$ & $\begin{array}{c}104.5 \pm 5.58^{\mathrm{a}, \mathrm{b}, \mathrm{d}} \\
114 \% \uparrow\end{array}$ & $\begin{array}{c}91.85 \pm 0.41^{\text {a,b.d }} \\
4 \% \downarrow\end{array}$ & $\begin{array}{c}92.58 \pm 3.04^{\mathrm{a}, \mathrm{b}} \\
68 \% \uparrow\end{array}$ \\
\hline & Mixture & $\begin{array}{c}73.03 \pm 1.97^{\mathrm{b}, \mathrm{c}} \\
1 \% \uparrow\end{array}$ & $\begin{array}{c}55.04 \pm 1.12^{\mathrm{a}, \mathrm{b}} \\
16 \% \downarrow\end{array}$ & $\begin{array}{c}62.19 \pm 1.49^{\mathrm{a}, \mathrm{b}, \mathrm{c}} \\
28 \% \uparrow\end{array}$ & $\begin{array}{c}93.43 \pm 0.10^{\mathrm{a}, \mathrm{c}} \\
2 \% \downarrow\end{array}$ & $\begin{array}{c}86.51 \pm 2.67^{\mathrm{a}, \mathrm{b}} \\
57 \% \uparrow\end{array}$ \\
\hline $\begin{array}{l}\text { eans } \pm S . E \\
\text { e arrows i } \\
b, c, d: S\end{array}$ & $\begin{array}{l}\text { the same letters } \\
\text { ate an increase in } \\
\text { cance comparing }\end{array}$ & $\begin{array}{l}\text { same column ar } \\
\text { y } \% \uparrow \text { or decreas } \\
\text { ontrol, glyphosat }\end{array}$ & $\begin{array}{l}\text { icantly different } \\
\text { y } \% \downarrow \text { compared } \\
n \text { and mixture re }\end{array}$ & & & \\
\hline
\end{tabular}

Table 1: Mean \pm S.E of antioxidative parameters (SOD, CAT, GST, GSH and MDA) in gills and liver tissues of Nile tilapia after 4 days exposure to applied pollutants.

and glyphosate herbicide also, activity of cadmium increased due to its high toxicity.

But, data of oxidative parameters for liver after short time of exposure 4 days with high concentration $96 \mathrm{~h}-\mathrm{LC}_{50}$ showed significantly reduced activity of SOD, CAT and GSH in $\mathrm{CdCl}_{2}$ treatment followed by glyphosate and mixture, respectively. Where, reduction activity due to short time of exposure and liver cells take long time to store toxicants. Activity of GST and MDA significantly increased in $\mathrm{CdCl}_{2}$ treatment followed by glyphosate and mixture where, elevated activity due to high concentration of pollutants which represent $\mathrm{LC}_{50}$.

Many studies through exposure period of 4 days to pollutants gave similar results to the result of this study such as inhibition activity of GST was observed in goldfish exposed for 96 hrs to Roundup [43]. Also, significant reduction in serum GSH, increase in SOD, MDA of Nile tilapia via exposure period $96 \mathrm{~h}-\mathrm{LC}_{50}$ concentration [44]. Gills of Labeo rohita exposed to $33.6,67.1$, and $100.6 \mathrm{mg} / \mathrm{l}$ of cadmium chloride at $96 \mathrm{hrs}$ led to oxidative stress where activity of LPO increased in all treated groups but in case of catalase decreased [45]. CAT activity has been inhibited in fish species exposed to pesticides such as deltamethrin [23].

Although the activity of CAT increase in liver occurred in response to increased levels of ROS [46]. The increasing of catalase and lipid peroxidation activity in gills by using $116 \mu \mathrm{g} / \mathrm{L}$ of Roundup but the decreasing of superoxide dismutase activity in liver after 3 days of exposure of Anguilla anguilla fish [47].

Also, CAT and SOD activity increased significantly in muscle and brain tissues after exposure to different concentrations of Cd for $96 \mathrm{hrs}$ compared with control [48]. After 96 hrs of exposure of Oreochromis mossambicus to endosulfan activities of CAT, SOD and GST in gill and liver cells showed significant increase in activity of all the three enzymes [49]. Also, exposed liver, kidney and gill cells of Oreochromis niloticus to $1 / 2$ and $1 / 3$ median lethal concentration $\left(96 \mathrm{hrs}-\mathrm{LC}_{50}\right.$ ) of di-n-butyl phthalate (DBP) through the period of 4 days showed that significant increase in activity of MDA and inhibition of SOD activity and GSH level in the group that was exposed to higher concentration of DBP [50].
So, data presented in Table 2 indicate that the effect of $1 / 4 \mathrm{LC}_{50}$ of glyphosate, $\mathrm{CdCl}_{2}$ and mixture treatment on the activity of antioxidant enzymes is due to oxidative stress on gills and liver of Oreochromis niloticus after 8 days. Data of oxidative parameters for gills at moderate time of exposure 8 days with little high concentration $1 / 4 \mathrm{LC}_{50}$ showed significantly reduced activity of SOD in $\mathrm{CdCl}_{2}$ treatment followed by glyphosate and mixture, respectively. High reduction activity of SOD in $\mathrm{CdCl}_{2}$ treatment is because that gills don't keep sufficient amount of $\mathrm{CdCl}_{2}$ which can cause oxidative stress. Reduction activity of CAT of glyphosate treatment is due oxidative stress was not very strong but, activity of CAT increased in treatment of mixture and $\mathrm{CdCl}_{2}$ is due to strong oxidative stress. Activity of GST and GSH nearly was not significant otherwise, activity of GST significantly increased in mixture treatment due to presence of synergistic effect between $\mathrm{CdCl}_{2}$ and glyphosate which caused strong oxidative stress. Also, the little increasing of activity of GST in $\mathrm{CdCl}_{2}$ was because of cadmium is nonessential element causes oxidative stress. Also, elevated activity of MDA in all treatments is due to quite long exposure period.

But data of oxidative parameters for liver at moderate time of exposure 8 days with rather high concentration $1 / 4 \mathrm{LC}_{50}$ showed significantly reduced activity of SOD, CAT and GSH in $\mathrm{CdCl}_{2}$ treatment followed by glyphosate and mixture, respectively. Where, reduction activity causing by the time of exposure considered short and oxidative stress altered gene expression of these antioxidant enzymes. But SOD activity significantly increased in mixture treatment is due to the synergistic effect between $\mathrm{CdCl}_{2}$ and glyphosate which caused strong oxidative stress. Activity of GST and MDA significantly increased in glyphosate treatment followed by $\mathrm{CdCl}_{2}$ and mixture. Where, elevated activity due to high concentration of pollutants which represent $1 / 4 \mathrm{LC}_{50}$ and moderate exposure period.

Also, many studies illustrated that Oxidative stress in exposed gills of Nile tilapia to two types of glyphosate formulations through 3, 7, 14 days show increase activity of MDA but activity of SOD, CAT, GSH and GST decrease but in liver show increase activity of MDA and CAT but SOD, GSH and GST decrease [51]. Fish species which exposed to cadmium show variation of GSH activity due to the exposure period and the type of pollutant. Also, increasing and decreasing in GSH 
Citation: Abd-Allah MM, Ramadan A A, Said NM, Ibrahim IH, Abdel-karim EA (2019) Effects of Cadmium Chloride and Glyphosate on Antioxidants as Biochemical Biomarkers in Nile Tilapia. J Aquac Res Development 10: 561. doi: 10.4172/2155-9546.1000561

Page 4 of 6

\begin{tabular}{|c|c|c|c|c|c|c|}
\hline \multirow{3}{*}{ Tissues } & \multicolumn{6}{|c|}{ Exposure period (192 hrs) 8 days with $1 / 4 \mathrm{LC}_{50}$} \\
\hline & \multirow{2}{*}{$\begin{array}{l}\text { Oxidative stress } \\
\text { treatments }\end{array}$} & \multicolumn{5}{|c|}{ Enzymatic \& non-enzymatic antioxidants Mean \pm S.E) } \\
\hline & & SOD & CAT & GST & GSH & MDA \\
\hline \multirow{4}{*}{ Gills } & Control & $74.34 \pm 1.95^{\mathrm{b}, \mathrm{c}, \mathrm{d}}$ & $22.88 \pm 0.58^{\mathrm{b}, \mathrm{c}, \mathrm{d}}$ & $18.06 \pm 0.22^{\mathrm{d}}$ & $87.50 \pm 0.94^{b}$ & $61.08 \pm 0.29^{b, c, d}$ \\
\hline & Glyphosate & $\begin{array}{c}59.92 \pm 2.58^{\mathrm{a}, \mathrm{c}} \\
19 \% \downarrow\end{array}$ & $\begin{array}{c}12.02 \pm 0.83^{\mathrm{a}, \mathrm{c}, \mathrm{d}} \\
47 \% \downarrow\end{array}$ & $\begin{array}{c}18.05 \pm 0.44^{\mathrm{d}} \\
0.05 \% \downarrow\end{array}$ & $\begin{array}{c}84.91 \pm 0.36^{\mathrm{a}, \mathrm{c}, \mathrm{d}} \\
3 \% \downarrow\end{array}$ & $\begin{array}{c}78.32 \pm 2.82^{\mathrm{a}, \mathrm{d}} \\
28 \% \uparrow\end{array}$ \\
\hline & Cadmium & $\begin{array}{c}49.81 \pm 1.89^{\mathrm{a}, \mathrm{b}, \mathrm{d}} \\
33 \% \downarrow\end{array}$ & $\begin{array}{c}28.70 \pm 2.27^{\mathrm{a}, \mathrm{b}, \mathrm{d}} \\
25 \% \uparrow\end{array}$ & $\begin{array}{c}19.44 \pm 0.37^{d} \\
8 \% \uparrow\end{array}$ & $\begin{array}{c}87.51 \pm 0.18^{b} \\
0.01 \% \uparrow\end{array}$ & $\begin{array}{c}77.57 \pm 1.64^{\mathrm{a}, \mathrm{d}} \\
27 \% \uparrow\end{array}$ \\
\hline & Mixture & $\begin{array}{c}63.59 \pm 1.31^{\mathrm{a}, \mathrm{c}} \\
14 \% \downarrow\end{array}$ & $\begin{array}{c}38.86 \pm 2.92^{\mathrm{a}, \mathrm{b}, \mathrm{c}} \\
70 \% \uparrow\end{array}$ & $\begin{array}{c}21.67 \pm 0.77^{\mathrm{a}, \mathrm{b}, \mathrm{c}} \\
20 \% \uparrow\end{array}$ & $\begin{array}{c}87.41 \pm 0.56^{\mathrm{b}} \\
0.01 \% \downarrow\end{array}$ & $\begin{array}{c}71.20 \pm 1.10^{\mathrm{a}, \mathrm{b}, \mathrm{c}} \\
16 \% \uparrow\end{array}$ \\
\hline \multirow{4}{*}{ Liver } & Control & $72.46 \pm 1.73^{d}$ & $65.91 \pm 4.24^{\mathrm{c}, \mathrm{d}}$ & $48.372 \pm 3.1^{b, c, d}$ & $95.55 \pm 0.23^{b, c, d}$ & $55.22 \pm 2.48^{b, c, d}$ \\
\hline & Glyphosate & $\begin{array}{c}71.57 \pm 1.37^{\mathrm{d}} \\
1 \% \downarrow\end{array}$ & $\begin{array}{c}72.67 \pm 1.41^{\mathrm{c}, \mathrm{d}} \\
10 \% \uparrow\end{array}$ & $\begin{array}{c}72.68 \pm 1.93^{\mathrm{a}, \mathrm{c}, \mathrm{d}} \\
49 \% \uparrow\end{array}$ & $\begin{array}{c}90.37 \pm 0.99^{\mathrm{a}} \\
5 \% \downarrow\end{array}$ & $\begin{array}{c}92.02 \pm 1.68^{\mathrm{a}, \mathrm{d}} \\
67 \% \uparrow\end{array}$ \\
\hline & Cadmium & $\begin{array}{c}72.09 \pm 1.33^{\mathrm{d}} \\
0.5 \% \downarrow\end{array}$ & $\begin{array}{c}51.21 \pm 2.29^{\mathrm{a}, \mathrm{b}} \\
22 \% \downarrow\end{array}$ & $\begin{array}{c}65.74 \pm 0.87^{\mathrm{a}, \mathrm{b}, \mathrm{d}} \\
35 \% \uparrow\end{array}$ & $\begin{array}{c}88.70 \pm 0.13^{\mathrm{a}} \\
7 \% \downarrow\end{array}$ & $\begin{array}{c}88.67 \pm 2.41^{\mathrm{a}, \mathrm{d}} \\
60 \% \uparrow\end{array}$ \\
\hline & Mixture & $\begin{array}{c}84.18 \pm 1.45^{\mathrm{a}, \mathrm{b}, \mathrm{c}} \\
16 \% \uparrow\end{array}$ & $\begin{array}{c}55.69 \pm 1.97^{\mathrm{a}, \mathrm{b}} \\
15 \% \downarrow\end{array}$ & $\begin{array}{c}59.33 \pm 1.31^{\mathrm{a}, \mathrm{b}, \mathrm{c}} \\
22 \% \uparrow\end{array}$ & $\begin{array}{c}88.79 \pm 0.56^{\mathrm{a}} \\
7 \% \downarrow\end{array}$ & $\begin{array}{c}76.05 \pm 1.71^{\mathrm{a}, \mathrm{b}, \mathrm{c}} \\
38 \% \uparrow\end{array}$ \\
\hline
\end{tabular}

Means \pm S.E with the same letters in the same column are not significantly different $(p>0.05)$.

Table 2: Mean \pm S.E of antioxidative parameters (SOD, CAT, GST, GSH and MDA) in gills and liver tissues of Nile tilapia after 8 days exposure to applied pollutants.

\begin{tabular}{|c|c|c|c|c|c|c|}
\hline \multirow{3}{*}{ Tissues } & \multicolumn{6}{|c|}{ Exposure period 45 days with $1 / 10 \mathrm{~L}_{c 5} 0$} \\
\hline & \multirow{2}{*}{$\begin{array}{l}\text { Oxidative stress } \\
\text { treatments }\end{array}$} & \multicolumn{5}{|c|}{ Enzymatic \& Non-Enzymatic Antioxidants (Mean \pm S.E) } \\
\hline & & SOD & CAT & GST & GSH & MDA \\
\hline \multirow{4}{*}{ Gills } & Control & $74.34 \pm 1.95^{c}$ & $22.88 \pm 0.58^{\mathrm{b}, \mathrm{c}, \mathrm{d}}$ & $18.06 \pm 0.22^{\mathrm{b}, \mathrm{c}, \mathrm{d}}$ & $87.50 \pm 0.94^{b, c, d}$ & $61.08 \pm 0.29^{b, c, c}$ \\
\hline & Glyphosate & $\begin{array}{c}77.21 \pm 4.59 \\
4 \% \uparrow\end{array}$ & $\begin{array}{c}43.73 \pm 1.38^{\mathrm{a}, \mathrm{c}, \mathrm{d}} \\
91 \% \uparrow\end{array}$ & $\begin{array}{c}26.12 \pm 2.31^{\mathrm{a}, \mathrm{c}, \mathrm{d}} \\
45 \% \uparrow\end{array}$ & $\begin{array}{c}73.05 \pm 1.73^{\mathrm{a}} \\
16 \% \downarrow\end{array}$ & $\begin{array}{c}77.06 \pm 2.37^{\mathrm{a}} \\
26 \% \uparrow\end{array}$ \\
\hline & Cadmium & $\begin{array}{c}85.76 \pm 1.56^{\mathrm{a}, \mathrm{d}} \\
15 \% \uparrow\end{array}$ & $\begin{array}{c}36.89 \pm 0.86^{\mathrm{a}, \mathrm{b}} \\
61 \% \uparrow\end{array}$ & $\begin{array}{c}39.53 \pm 2.16^{\mathrm{a}, \mathrm{b}, \mathrm{d}} \\
119 \% \uparrow\end{array}$ & $\begin{array}{c}69.60 \pm 1.08^{\mathrm{a}} \\
20 \% \downarrow\end{array}$ & $\begin{array}{c}73.16 \pm 3.50^{\mathrm{a}} \\
20 \% \uparrow\end{array}$ \\
\hline & Mixture & $\begin{array}{c}73.52 \pm 3.22^{\mathrm{c}} \\
1 \% \downarrow\end{array}$ & $\begin{array}{c}38.05 \pm 0.81^{\mathrm{a}, \mathrm{b}} \\
66 \% \uparrow\end{array}$ & $\begin{array}{c}10.74 \pm 1.10^{\mathrm{a}, \mathrm{b}, \mathrm{c}} \\
40 \% \downarrow\end{array}$ & $\begin{array}{c}69.83 \pm 1.69^{\mathrm{a}} \\
20 \% \downarrow\end{array}$ & $\begin{array}{c}80.07 \pm 6.08^{\mathrm{a}} \\
31 \% \uparrow\end{array}$ \\
\hline \multirow{4}{*}{ Liver } & Control & $72.46 \pm 1.73^{b, c}$ & $65.91 \pm 4.24$ & $48.372 \pm 3.1^{\mathrm{b}, \mathrm{c}}$ & $95.55 \pm 0.23^{b, c, d}$ & $55.22 \pm 2.48^{d}$ \\
\hline & Glyphosate & $\begin{array}{c}102.9 \pm 1.06^{\mathrm{a}, \mathrm{c}, \mathrm{d}} \\
42 \% \uparrow\end{array}$ & $\begin{array}{c}71.97 \pm 1.60^{\mathrm{c}, \mathrm{d}} \\
9 \% \uparrow\end{array}$ & $\begin{array}{c}30.49 \pm 1.05^{\mathrm{a}, \mathrm{d}} \\
37 \% \downarrow\end{array}$ & $\begin{array}{c}78.91 \pm 1.95^{\mathrm{a}, \mathrm{c}, \mathrm{d}} \\
17 \% \downarrow\end{array}$ & $\begin{array}{c}63.41 \pm 0.44^{d} \\
15 \% \uparrow\end{array}$ \\
\hline & Cadmium & $\begin{array}{c}47.45 \pm 2.20^{\mathrm{a}, \mathrm{b}, \mathrm{d}} \\
34 \% \downarrow\end{array}$ & $\begin{array}{c}59.04 \pm 2.02^{\mathrm{b}} \\
10 \% \downarrow\end{array}$ & $\begin{array}{c}27.39 \pm 1.59^{\mathrm{a}, \mathrm{d}} \\
44 \% \downarrow\end{array}$ & $\begin{array}{c}69.25 \pm 1.79^{\mathrm{a}, \mathrm{b}, \mathrm{d}} \\
27 \% \downarrow\end{array}$ & $\begin{array}{c}62.90 \pm 5.11^{\mathrm{d}} \\
14 \% \uparrow\end{array}$ \\
\hline & Mixture & $\begin{array}{c}75.62 \pm 1.92^{\mathrm{b}, \mathrm{c}} \\
4 \% \uparrow\end{array}$ & $\begin{array}{c}58.62 \pm 2.56^{b} \\
11 \% \downarrow\end{array}$ & $\begin{array}{c}43.57 \pm 1.51^{\mathrm{b}, \mathrm{c}} \\
10 \% \downarrow\end{array}$ & $\begin{array}{c}63.87 \pm 0.89^{a, b, c} \\
33 \% \downarrow\end{array}$ & $\begin{array}{c}76.61 \pm 2.59^{\mathrm{a}, \mathrm{b}, \mathrm{c}} \\
39 \% \uparrow\end{array}$ \\
\hline
\end{tabular}

Table 3: Mean \pm S.E of antioxidative parameters (SOD, CAT, GST, GSH and MDA) in gills and liver tissues of Nile tilapia after 45 days exposure to applied pollutants.

activity have been observed, depending on field and experimental conditions [52,53]. Thus, SOD and CAT levels changed in all tissues of fresh water fish Grass Carp, Ctenopharyngodon Idella after the exposed period 10 and 15 days with $1 / 10^{\text {th }}$ ( 96 hrs of $\mathrm{LC}_{50}$ ) of chlorantraniliprole. Superoxide dismutase (SOD) and Catalase (CAT) levels changed in all tissues, when compared to control groups at sublethal concentration [54]. Glutathione reductase was significantly increased in liver cells of juvenile brown trout exposed to glyphosate and Roundup for 14 days [55]. Oxidative stress specially SODS and CAT in liver tissues of Nile tilapia exposed to $\mathrm{CdCl}_{2}$ for 15 days showed activity significantly increased [56]. The results of actual study differ from some studies where SOD activity significantly increased in gills and liver. CAT activity is little in liver and there was not any alteration in gills. MDA activity had no alterations in gills and reduced in liver compared to control of Nile tilapia exposed to parabens after 12 days [57]. Oxidative stress showed activity reduction of SOD and CAT but significant increasing of MDA in liver tissues of Nile tilapia which exposed to pendimethalin after 28 days [58]. So, data presented in Table 3 indicate that the effect of
$1 / 10 \mathrm{LC}_{50}$ of glyphosate, $\mathrm{CdCl}_{2}$ and mixture treatment on the activity of antioxidant enzymes is due to oxidative stress on gills and liver tissues of Oreochromis niloticus after 45 days. Data of oxidative parameters for gills at long time of exposure 45 days with low concentration $1 / 10 \mathrm{LC}_{50}$ showed significantly increased activity of SOD in $\mathrm{CdCl}_{2}$ more than glyphosate treatment because of high toxicity of cadmium but happened very simple reduction activity in mixture treatment where, occurrence start of antagonistic effect between of $\mathrm{CdCl}_{2}$ and glyphosate treatment. Significantly increased activity of CAT and MDA in glyphosate followed by mixture and $\mathrm{CdCl}_{2}$ treatment due to the long of exposure period and took place high synergistic effect between $\mathrm{CdCl}_{2}$ and glyphosate herbicide. Activity increased of GST in $\mathrm{CdCl}_{2}$ is due to its high toxicity and in glyphosate due to its formulation. But, reduction activity of GST in mixture treatment is due to occurrence of antagonistic effect between $\mathrm{CdCl}_{2}$ and glyphosate. Reduction activity of GSH in glyphosate, $\mathrm{CdCl}_{2}$ and mixture treatment nearly with equal portions causing by the low concentration of pollutants. 
Citation: Abd-Allah MM, Ramadan A A, Said NM, Ibrahim IH, Abdel-karim EA (2019) Effects of Cadmium Chloride and Glyphosate on Antioxidants as Biochemical Biomarkers in Nile Tilapia. J Aquac Res Development 10: 561. doi: 10.4172/2155-9546.1000561

Page 5 of 6

But, data of oxidative parameters for liver at long time of exposure 45 days with high concentration $1 / 10 \mathrm{LC}_{50}$ showed significantly reduced activity of SOD in $\mathrm{CdCl}_{2}$ treatment where, liver performing storage of $\mathrm{Cd}$ element causing oxidative stress led to reduced activity. But, increased activity of SOD in glyphosate treatment is because of POEA formulation causing high oxidative stress and in mixture treatment is due to start of synergistic effect between $\mathrm{CdCl}_{2}$ and glyphosate herbicide. Significantly reduced activity of CAT, GST and GSH in all treatments is due to liver could store sufficient amount of pollutants causing strong oxidative stress cause reduction of activity. But simple significantly increased of CAT in glyphosate treatment due to long exposure period and low oxidative stress. Activity increased of MDA in mixture followed by glyphosate and cadmium due to low concentration of pollutants.

These results are similar to Rathnamma and Nagaraju [59] where, increasing the exposure period and toxicant concentration of chlorantraniliprole led to increase in SOD and CAT in all tissues of exposed freshwater fish Ctenopharyngodon Idella compared to control fish. In addition to the activity of GST decreased in liver of Nile tilapia exposed to glyphosate-based herbicide formulation of POEA which act as an oxidizing agent inhibiting activity of GST [60]. Oxidative stress on gills and liver of Nile tilapia exposed to cadmium ( $5 \mathrm{mg} /$ liter water) through periods of 7,21, 42 days showed that there are no significant changes of reduced glutathione in liver cells at 7 days of exposure and increased at 21 and 42 days but in gills, GSH levels no significantly at all periods. GST significantly increased in liver cells at 7, 21 and 42 days but in gills, there was no significantly at all periods, also CAT activity in liver was no significant at 7 and 21 days of exposure period compared with the control. However, CAT activity increased significantly at 42 days of exposure period but in gills, were no significantly at all experimental periods. MDA activity in liver was significantly increased at all experimental periods but in gills, was significantly increased at 42 days only [61]. Exposed liver cells of Oreochromis niloticus to diclofenac (DCF) for 30 days showed activity of CAT inhibited, GSH level decreased and the increase in the activities of SOD and GST [62]. Results of actual study are different from other studies where serum malondialdehyde (MDA) activity was significantly reduced while activity of glutathione reductase significantly increased and no significant for CAT, SOD activity compared to control of Nile tilapia after 56 days [63]. N-acetyl cysteine (NAC) caused decreasing activity of MDA in liver, increasing activity of GST in plasma and activity of SOD increased in liver of Oreochromis niloticus after 8 weeks [64].

\section{Conclusion}

From the results it can be concluded that the activities and expression levels of antioxidant enzymes and oxidative stress can be used as biomarkers to evaluate the influence of $\mathrm{CdCl}_{2}$, glyphosate and their mixture on the biochemical pathway and enzymatic function in Nile tilapia that can be used for biological monitoring of environmental contamination.

\section{References}

1. Authman MMN, Zaki MS, Khallaf EA, Abbas HH (2015) Use of Fish as Bioindicator of the Effects of Heavy Metals Pollution. J Aqua Res Develop 6: 1-13.

2. Taweel A, Shuhaimi-Othman M, Ahmad AK (2011) Heavy metal concentration in different organs of tilapia fish (Oreochromis niloticus) from selected areas of Bangi, Selangor, Malaysia. Afr J Biotech 10: 11562-11566.

3. Sadek SS (2011) An overview on desert aquaculture in Egypt. In V. Crespi and Lovatelli, eds. Aquaculture in desert and arid lands: development constraints and opportunities. FAO Fisheries and Aquaculture Proceedings No. 20. Rome, Italy. 141-158p.
4. Macfadyen G, Nasr-Allah AM, Dickson M (2012) The market for Egyptian farmed fish. World Fish Center, Egypt: 1-48p.

5. Samy KM (2015) Status of fisheries in Egypt: reflections on past trends and management challenges. Rev Fish Biol Fish 25(4): 631-649.

6. Ibrahim $\mathrm{HI}$ (2000) Genetic studies on some tilapia species under different salinity conditions. Ain Shams Univ, Faculty of Agriculture, Genetics Department, Cairo, Egypt.

7. El-Wakil HF, Seehy MA, El-Dahhar AA, Ibrahim MM, Hemeida AA, et al. (2008) The effect of environmental condition on genetic background in Nile tilapia (Oreochromis niloticus). J Arab Aqua Soc 5(1): 101-118.

8. Vieira C, Morais S, Ramos S, Delerue-Matos C, Oliveira MB (2011) Mercury cadmium, lead and arsenic levels in three pelagic fish species from the Atlantic Ocean: Intra-and inter-specific variability and human health risks for consumption. Food Chem Toxic 49: 923-932.

9. Yoon SSH, Rana SVS (2008) Molecular markers of heavy metal toxicity-A new paradigm for health risk assessment. J Environ Biol 29: 1-14.

10. Jitar O, Teodosiu C, Oros A, Plavan G, Nicoara M (2014) Bioaccumulation of heavy metals in marine organisms from the Romanian sector of the Black Sea. N Biotechnol 32: 369-378.

11. Dangre AJ, Manning S, Brouwer M (2010) Effects of cadmium on hypoxiainduced expression of hemoglobin and erythropoietin in larval sheep head minnow, Cyprinodon variegates. Aquatic Toxic 99: 168-175.

12. Ayoola SO (2008) Toxicity of glyphosate herbicide on Nile tilapia (Oreochromis niloticus) juvenile. Afr J Agric Res 3: 825-834.

13. Tsui MT, Chu LM (2008) Environmental fate and non-target impact of glyphosate-based herbicide (Roundup) in a subtropical wetland. Chemosphere 71: 439-446.

14. World Health Organization, (1994) Glyphosate Environ Health Criteria 159.

15. Brausch JM, Smith PN (2007) Toxicity of three polyethoxylated tallow amine surfactant formulations to laboratory and field collected fairy shrimp Thamnocephalus platyurus. Arch Environ Cont Toxic 52: 217-221.

16. Newani CD, Nagpure NS, Kumar R, Kushwaha B, Lakra WS (2013) DNA damage and oxidative stress modulatory effects of glyphosate- based herbicide in freshwater fish, Channa punctatus. Environ. Toxicol. Pharmacol 36: 539-547.

17. Lakra WS, Nagpure NS (2009) Genotoxicological studies in fish: a review. Indian J Anim Sci 79: 93-98.

18. Nishida $Y$ (2011) The chemical process of oxidative stress by copper (II) and iron (III) ions in several neurodegenerative disorders. Monatshefte fur Chemie 142: $375-384$

19. German JB (1999) Food processing and lipid oxidation. Adv Exp Med Biol 459: 23-50.

20. Glusczak L, Miron DS, Crestani M, Fonseca MB, Pedron FA, et al. (2006) Effect of glyphosate herbicide on acetylcholinesterase activity and metabolic and hematological parameters in piava (Leporinus obtusidens). Ecotoxic Environ Saf 65: 237-241.

21. Van Leyen K, Duvoisin RM, Engelhardt H, Wiedmann M (1998) A function for lipoxygenase in programmed organelle degradation. Nature 5: 395-392.

22. Feussner I, Kühn H, Wasternack C (2001) Lipoxygenase-dependent degradation of storage lipids. Trends Plant Sci 6: 268-273.

23. Yonar ME, Sakin F (2011) Ameliorative effect of lycopene on antioxidant status in Cyprinus carpio during pyrethroid deltamethrin exposure. Pest Biochem 9: 226-231.

24. Bergamini CM, Gambetti S, Dondi A, Cervellati C (2004) Oxygen reactive species and tissue damage. Curr Pharm Des10: 1611-1626.

25. Dipak KS, Sripad CP, Gagan BC (2013) A comparative study of catalase activities in different vertebrates. 40546-0236-USA

26. Glusczak L, Miron DS, Moraes BS, Simoes RR, Schetinger MRC, et al. (2007) Acute effects of glyphosate herbicide on metabolic and enzymatic parameters of silver catfish (Rhamdia quelen). Bio Physiol C 146: 519-524.

27. Lenartova V, Holovska K, Pedrajas JR, Martinez Lara E, Peinado J, et al. (2005) Antioxidant and detoxifying fish enzymes as biomarkers of river pollution. Biomarkers 2: 247-252. 
Citation: Abd-Allah MM, Ramadan A A, Said NM, Ibrahim IH, Abdel-karim EA (2019) Effects of Cadmium Chloride and Glyphosate on Antioxidants as Biochemical Biomarkers in Nile Tilapia. J Aquac Res Development 10: 561. doi: 10.4172/2155-9546.1000561

28. Ferrari A, Venturino A, Peche'n de D'Angelo and A. M. (2007): Effects of carbaryl and azinphos methyl on juvenile rainbow trout (Oncorhynchus mykiss) detoxifying enzymes. Pest Bio Physiol 88: 134-142.

29. Goetz ME, Luch A (2008) Reactive species: a cell damaging rout assisting to chemical carcinogens. Cancer Lett 266: 73-83.

30. Maran E, Fernandez M, Barbieri P, Font G, Ruiz MJ (2009) Effects of four carbamate compounds on antioxidant parameters. Ecotoxic. Environ. Saf 72 922-930.

31. Shalaby AME, Ramadan AA, El-Khattab YA(2005) Haematological, biochemica and histological changes on Nile tilapia to chronic saturn (thiothiobencarb) and glyphosate intoxication. Egypt J Appl Sci 20: 455-479.

32. OECD (Organization for Economic Cooperation and Development) (1992) Guideline for the testing of chemicals: Fish, acute toxicity test, Document-203.

33. Weil SC (1952) Tables for convenient calculation of median effective dose (LD50 or ED50) and instructions in their use. Biometrics 8: 249-264.

34. Aebi H (1984) Catalase in vitro in L. Placer. F. L. Or-land Methods of enzymology Press New York, USA; 105p.

35. Marklund SL, Marklund G (1974) Involvement of the superoxide anion radical in the autoxidation of pyrogallol and a convenient assay for superoxide dismutase. Eur J Bio 47: 469-474.

36. Beutler E, Duron O, Kelly BM (1963) Improved method for the determination of blood glutathione. J Lab Clin Med 61: 882-888.

37. Habig WH, Pabst MJ, Jacoby WB (1974) Glutathione-S-transferees: the firs step in mercapturic fermentation. J Bio 249: 7130-7139.

38. Ohkawa H, Ohishi N, Yagi K (1979) Assay for lipid peroxides in animal tissues by thiobarbituric acid reaction. Anal Bio 95: 351-358.

39. Sokal RR, Rohlf FU (1969) The principles and practice of statistics in biological research. Freeman, San Francisco, USA.

40. Monteiro DA, Almeida JA, Rantin FT, Kalinin AL (2006) Oxidative stress biomarkers in the freshwater characid fish, $\mathrm{Br}$ yconcephalus, exposed to organophosphorus insecticide Folisuper 600 (methyl parathion). Comp Bio Physio C 143: 141-149.

41. Dogan D, Can C, Kocyigit A, Dikilitas M, Taskin A, et al. (2011) Dimethoate induced oxidative stress and DNA damage in Oncorhynchus mykiss. Chemosphere 84: 39-46.

42. Jin Y, Zheng S, Pu Y, Shu L, Sun L, et al. (2011) Cypermethrin has the potentia to induce hepatic oxidative stress, DNA damage and apoptosis in adult zebrafish (Danio rerio). Chemosphere 82: 398-404.

43. Lushchak O, Kubrak O, Storey K, Lushchak V (2009) Low toxic herbicide Roundup induces mild oxidative stress in gold fish tissues. Chemosphere 76 932-937.

44. Abu Zeid EH, Shimaa AL, Khalil A (2014) Effects of acute fenitrothion insecticide exposure on DNA damage and oxidative stress biomarkers and health of nile tilapia fingerlings, Oreochromis niloticus L. World J Fish and Marine Sci 6: 361 370.

45. Dabas A, Nagpure NS, Mishra RM, Kushwaha B, Kumar R, et al. (2012) Investigation of cadmium-induced genotoxicity and oxidative stress response in Indian Major Carp, (Labeo rohita). Hum Ecol Risk Assess: An Intern J 20: 510-526.

46. Moraes BS, Loro VL, Glusczak L, Pretto A, Meneze C, et al. (2007) Effects of four rice herbicides on some metabolic and toxicology parameters of teleost fish (Leporinus obtusidens). Chemosphere 68: 1597-1601.

47. Guilherme S, Santos MA, Gaivão I, Pacheco M (2011) European eel (Anguilla anguilla) genotoxic and pro-oxidant responses following short-term exposure to Roundup a glyphosate-based herbicide. Mutagenesis 25: 523-530.

48. Wang L, Abeer GA, Yan Y (2017) Biochemical changes in the tissues of Zebrafish (Danio rerio) exposed to organophosphorus pesticides and heavy metal cadmium. Int J Enviro Sci Develop 8: 707-714.

49. Kumar N, Antony JP, Pal AK, Remya S, Aklakur MD, et al. (2011) Anti-oxidative and immuno-hematological status of tilapia (Oreochromis mossambicus) during acute toxicity test of endosulfan. Pest Biochem Physiol 99: 45-52.

50. Khalil SR, Abd Elhakim Y, El-Murr AE (2017) Sub-lethal concentrations of di-nbutyl phthalate promote biochemical changes and DNA damage in juvenile Nile tilapia (Oreochromis niloticus). J Vet Res 64: 67-80.

51. Nahas AA, Aly FA, Reem MZ (2016) Biochemical responses of freshwater fish Oreochromis niloticus to glyphosate-based herbicides in relation to physicochemical properties. Egy Sci J Pestic 2: 96-101.

52. Cao L, Huang W, Liu J, Yin X, Dou S (2010) Accumulation and oxidative stress biomarkers in Japanese floun 7 der larvae and juveniles under chronic cadmium exposure. Comp Biochem Physiol C 151: 386-392.

53. Jia $X$, Zhang $H$, Liu $X$ (2011) Low levels of cadmium exposure induce DNA damage and oxidative stress in the liver of Oujiang colored common carp (Cyprinus carpio) var. color. Fish Physiol Bio 37: 97-103.

54. Mohsen K, Seyed RK, Ali AH (2012) Acute toxicity test of two pesticides diazinon and deltamethrin, on Swordtail Fish (Xiphophorus helleri). Glob Vet 8(5): 541-545.

55. Tamsyn MUW, Eduarda MS (2015) Global transcriptomic profiling demonstrates induction of oxidative stress and of compensatory cellular stress responses in brown trout exposed to glyphosate and Roundup. BMC Genomics 16: 32.

56. Jean AA, Rodrigo EB, Ethel LBN, Fabio JC, Sandro EM (2009) Oxidative stress biomarkers and aggressive behavior in fish exposed to aquatic cadmium contamination. Neotrop Ichthyol 7: 103-108.

57. Silva DC, Serrano L, Oliveira TMA, Mansano AS, Almeida EA et al. (2018) Effects of parabens on antioxidant system and oxidative damages in Nile tilapia (Oreochromis niloticus). Ecotoxicol Environ Saf (Netherlands) 162: 85-91.

58. Hamed HS, El-Sayed YS (2018) Antioxidant activities of Moringa oleifera lea extract against pendimethalin-induced oxidative stress and genotoxicity in Nile tilapia, Oreochromis niloticus (L.). Fish Physiol Biochem 44: 1-12.

59. Rathnamma VV, Nagaraju B (2014) Oxidative stress induced by chlorantraniliprole in various tissues of freshwater fish Ctenopharyngodon idella. J Med Sci Public Health 2: 21-27.

60. Bagnyukova TV, Chahrak OI, Lushchak VI (2006) Coordinated response of goldfish antioxidant defenses to environmental stress. Aqua Toxic 78: 325-331.

61. Ahmed ME, Khalid EA, Yasser SE (2014) Physiological and oxidative stress biomarkers in the freshwater Nile tilapia, Oreochromis Niloticus L, exposed to sublethal doses of cadmium. Alex J Vet Sci 40: 29-43.

62. Pandey PK, Ajima MNO, Kumar K, Poojary N, Kumar S (2017) Evaluation of DNA damage and physiological responses in Nile tilapia, Oreochromis niloticus (Linnaeus, 1758) exposed to sub-lethal diclofenac (DCF). Aqua Toxic 186: 205214

63. Larbi AC, Zhao J, Wu JW (2018) Replacement of fish oil with palm oil: Effects on growth performance, innate immune response, antioxidant capacity and disease resistance in Nile tilapia (Oreochromis niloticus). Plos One 13 e0196100.

64. Xie S, Zhou W, Tian L, Niu j (2016) Effect of N-acetyl cysteine and glycine supplementation on growth performance, glutathione synthesis, anti-oxidative and immune ability of Nile tilapia, Oreochromis niloticus. Fish Shellfish Immunol 55: $233-241$ 